\title{
Profil Kemampuan Pemecahan Masalah Siswa pada Pembelajaran Gerak Lurus
}

\author{
M. Hariri Mustofa ${ }^{\text {a) }}$, Dadi Rusdiana ${ }^{\text {b) }}$ \\ Prodi Pendidikan Fisika SPs UPI, Jl. Setiabudhi 229, Bandung 40153 \\ Email: ${ }^{a)}$ hariri.musyaffa@gmail.com, ${ }^{\text {b) }}$ dadirusdiana@upi.edu
}

\begin{abstract}
This study aims to determine the effect of the application models of learning are teachers doing the problem solving ability of students. The study was conducted in one of the class $\mathrm{X}$ State Senior High School in Sukabumi District, West Java Province. The method used is descriptive method. Samples were taken by using purposive sampling so have two classes totaling 35 students to look at their problem-solving abilities after following study conducted by the teacher of physics on the motion of matter straight. Data collection instruments used in this study was a questionnaire responses of students to the learning process of physics that teachers, test students' problem solving skills, and interview guides. Based on the analysis conclusion, the problem solving ability of students is highest in the indicator describing the problem with the percentage of $67.14 \%$ while the lowest is in the indicators to evaluate the solution with a percentage of $20 \%$. The average percentage of mastery of problem-solving ability is $52.57 \%$ so it concluded with the usual lesson the teacher is less to train higher level thinking skills, especially problem-solving abilities. Based on questionnaire responses and interviews can be concluded that the teacher had been teaching tend to use the same way in every meeting, the teacher explains the material then gives examples of questions and exercises so it is still quite teacher centered.
\end{abstract}

Keywords : Problem solving ability, student responses

\begin{abstract}
Abstrak
Penelitian ini bertujuan untuk mengetahui pengaruh penerapan model pembelajaran yang biasa dilakukan guru di kelas terhadap kemampuan pemecahan masalah siswa. Penelitian dilakukan di kelas X salah satu Sekolah Menengah Atas Negeri di Kabupaten Sukabumi Provinsi Jawa Barat. Metode penelitian yang digunakan adalah metode deskriptif. Sampel diambil dengan teknik purposive sampling sehingga dipilih dua kelas yang berjumlah 35 siswa untuk di lihat kemampuan pemecahan masalahnya setelah mengikuti pembelajaran Fisika yang dilakukan oleh guru pada materi gerak lurus. Instrumen pengumpulan data yang digunakan pada penelitian ini adalah tes kemampuan pemecahan masalah siswa, angket tanggapan siswa terhadap proses pembelajaran fisika yang dilakukan guru, dan pedoman wawancara. Berdasarkan hasil analisis data penelitian diperoleh kesimpulan bahwa kemampuan pemecahan masalah siswa yang paling tinggi adalah pada indikator mendeskripsikan masalah dengan persentase $67,14 \%$ sedangkan yang paling rendah adalah pada indikator mengevaluasi solusi dengan presentase $20 \%$. Rata-rata persentase penguasaan kemampuan pemecahan masalah adalah $52.57 \%$ sehingga disimpulkan pembelajaran yang biasa dilakukan guru kurang melatihkan keterampilan berpikir tingkat tinggi terutama kemampuan pemecahan masalah. Berdasarkan angket tanggapan dan wawancara diperoleh kesimpulan bahwa guru selama ini
\end{abstract}


mengajar cenderung menggunakan cara yang sama disetiap pertemuan yaitu guru menjelaskan materi kemudian memberikan contoh soal dan latihan soal sehingga masih tergolong teacher centered.

Kata Kunci: Kemampuan Pemecahan Masalah, Tanggapan Siswa.

\section{PENDAHULUAN}

Pembelajaran Fisika di SMA sebagaimana yang telah dirumuskan oleh pemerintah bertujuan untuk mengembangkan kemampuan bernalar dalam berpikir analisis induktif dan deduktif dengan menggunakan konsep dan prinsip Fisika untuk menjelaskan berbagai peristiwa alam dan menyelesaikan masalah baik secara kualitatif maupun kuantitatif (Depdiknas,2008). Oleh karena itu diselaraskan dengan karakter pendidikan abad 21, setelah pembelajaran Fisika diharapkan siswa tidak hanya memiliki kemampuan menguasai konsep dan prinsip Fisika saja (keterampilan berpikir dasar) tetapi juga memiliki kemampuan bernalar dalam berpikir analisis induktif dan deduktif (keterampilan berpikir kritis) dalam mengatasi masalah serta memiliki kemampuan mengembangkan pengetahuan dan sikap percaya diri (keterampilan berpikir kreatif) dalam menciptakan inovasi baru sehingga memiliki keterampilan hidup dan berkarir/keterampilan wirausaha (Trilling \& Fadel, 2009).

Persoalan sekarang adalah bagaimana menemukan cara yang terbaik untuk menyampaikan materi yang diajarkan sehingga siswa dapat memahami dan mengingat lebih lama materi yang diajar tersebut serta kemampuan pemecahan masalah Fisika siswa yang tinggi. Sebagai guru yang baik dan bijaksana harus mampu mengubah kesulitan pembelajaraan tersebut menjadi pembelalajaran aktif, kritis, efektif, dan menyenangkan. Hal ini tentu dengan kemampuan pemecahan masalah Fisika yang autentik dalam proses pembelajaran sangat perlu untuk ditonjolkan mengingat bahwa berusaha sendiri untuk mencari pemecahan masalah serta pengetahuan yang menyertainya, menghasilkan pengetahuan yang benar-benar bermakna, dan berusaha untuk mencari pemecahan masalah secara mandiri akan memberikan suatu pengalaman konkrit, dengan pengalaman tersebut dapat digunakan pula memecahkan masalah-masalah lain yang serupa, karena pengalaman itu memberikan makna tersendiri bagi peserta didik (Trianto, 2013).

"Suatu masalah dapat didefinisikan sebagai kesulitan yang terjadi pada diri seseorang ketika menghadapi suatu kasus yang solusi tidak didapatkan secara langsung" (Gok T. \& Silay, 2010). Pengertian tersebut memiliki arti bahwa masalah bisa hadir dalam bentuk apapun. Dalam hal ini problem solver tidak akan menemukan solusi atas permasalahan tersebut secara instan melainkan melalui sebuah proses. Selain itu unsur kesulitan bukan merupakan unsur intrinsik yang dimiliki suatu permasalahan melainkan lebih bergantung pada karakteristik problem solver.

Marzano (dalam Anita, 2007) menyatakan bahwa pemecahan masalah merupakan suatu proses yaitu proses berpikir atau proses mental dan aplikasi pengetahuan yang telah diperoleh. Secara sederhana, Gagne (dalam Purba,2003) memberikan batasan bahwa pemecahan masalah adalah suatu proses dimana siswa menentukan kombinasi dan aturan-aturan yang telah dipelajari sebelumnya yang dapat dipakai untuk memecahkan masalah yang dihadapi.

Menurut The National Science Teachers Association (NSTA) tahun 1985, pemecahan masalah merupakan kemampuan yang sangat penting yang harus dikembangkan dalam pembelajaran sains. Pemecahan masalah adalah hasil penerapan pengetahuan dan prosedur kepada suatu situasi masalah.

Salah satu cara menilai pemecahan masalah dalam pendidikan Fisika dilakukan dengan menggunakan analisis tugas prosedural. Hal ini didasarkan pada anggapan bahwa tahapan pemecahan masalah identik dengan tahapan memperoleh pengetahuan yang digunakan oleh para perencana sistem pengajaran. Analisis tugas prosedural (procedural task analysis atau task analysis atau task hierarchi analysis), digunakan untuk memecahkan tugas menjadi beberapa komponen, mengorganisasikan hubungan antara masing-masing tugas dan untuk menghasilkan penyelesaian masalah dengan efektif dan tepat (Depdiknas, 2008).

Heller (1999) menyatakan bahwa kemampuan pemecahan masalah dalam fisika dapat dilakukan dengan lima tahap seperti ditunjukkan pada TABEL 1. Berdasarkan tahapan pada TABEL 1, tahap satu dan tahap dua sama-sama meminta pemahaman siswa terhadap soal, mencerna dan 
memfokuskan permasalahan pada soal, oleh karena itu pada penelitian kali ini, untuk meminimalisir kerancuan, maka tahap satu dan tahap dua dilebur menjadi satu tahap, yaitu deskripsi masalah. Sehingga kriteria penilaian kemampuan pemecahan masalah didasarkan pada empat kriteria diantaranya adalah deskripsi masalah (pemahaman masalah), rencana solusi, melaksanakan solusi (ketepatan solusi), evaluasi solusi (ketepatan hasil).

TABEL 1. Tahapan kemampuan pemecahan masalah

\begin{tabular}{lll}
\hline No & Tahap Pemecahan Masalah & \\
\hline 1. Memvisualisa-sikan masalah & a) Menggambar sketsa yang menyatakan situasi masalah. \\
& & b) Mengidentifikasi variabel yang diketahui dan tidak diketahui. \\
& c) Menyatakan kembali pertanyaan. \\
& d) Mengidentifikasi pendekatan umum terhadap masalah, seperti \\
& & konsep dan prinsip fisika yang sesuai dengan situasi masalah.
\end{tabular}

2. Mendeskripsi-kan konsep fisika a) Menggunakan prinsip yang telah diidentifikasi untuk membuat berdasarkan masalah diagram.

b) Menuliskan simbol yang relevan dengan variabel yang diketahui dan tidak diketahui.

c) Menuliskan simbol yang spesifik untuk variabel yang dicari.

d) Mendeskripsikan hubungan kualitatif dari variabel-variabel yang terdapat pada masalah.

3. Merencanakan solusi

a) Nyatakan permasalahan dengan persamaan matematika.

b) Tuliskan persamaan lain yang dibutuhkan untuk menyelesaikan masalah.

4. Melaksanakan rencana solusi Substitusikan semua variabel yang diketahui ke dalam persamaan yang sesuai dan melakukan perhitungan.

5. Mengecek dan mengevaluasi

a) Cek apakah permasalahan telah terselesaikan seluruhnya. solusi

b) Mengevaluasi apakah jawaban yang diperoleh masuk akal.

Berdasarkan pemaparan tersebut dan mengingat pentingnya kemampuan pemecahan masalah dalam pembelajaran Fisika maka penelitian ini dilakukan untuk mendeskripsikan kemampuan pemecahan masalah siswa dalam pembelajaran gerak lurus pada salah satu SMA Negeri di Kabupaten Sukabumi.

\section{METODE PENELITIAN}

Metode yang digunakan dalam penelitian ini adalah metode deskriptif. Metode deskriptif digunakan untuk mendapatkan gambaran bagaimana proses pembelajaran Fisika di kelas yang selama ini dilakukan oleh guru dan bagaimana efeknya terhadap kemampuan pemecahan masalah siswa serta bagaimana tanggapan siswa terhadap proses tersebut.

Populasi dalam penelitian ini adalah siswa kelas X pada sebuah Sekolah Menengah Atas Negeri di Kabupaten Sukabumi. Sampel penelitian diambil secara purposive sampling karena pengambilan sampel menggunakan pertimbangan tertentu (Sugiyono, 2013). Sehingga dipilih siswa pada dua kelas sebagai sampel dengan jumlah 35 siswa karena siswa pada dua kelas tersebut sedang membahas materi pelajaran Fisika yang sama yaitu tentang gerak lurus. Bentuk instrumen yang digunakan dalam penelitian ini disajikan pada TABEL 2.

TABEL 2. Instrumen penelitian

\begin{tabular}{lcl}
\hline Bentuk instrumen & Sumber data & \multicolumn{1}{c}{ Keterangan } \\
\hline $\begin{array}{l}\text { Tes Kemampuan } \\
\text { Pemecahan }\end{array}$ & Siswa & $\begin{array}{l}\text { Kemampuan pemecahan masalah yang } \\
\text { terintegrasi dalam soal-soal tentang materi } \\
\text { Masalah }\end{array}$ \\
Angket & Siswa & $\begin{array}{l}\text { Angket tanggapan siswa tentang } \\
\text { pembelajaran Fisika. }\end{array}$ \\
Wawancara & Siswa dan Guru & Proses pembelajaran Fisika yang dilakukan. \\
\hline
\end{tabular}


Tes kemampuan pemecahan masalah diberikan pada akhir pembelajaran materi gerak lurus. Indikator kemampuan pemecahan masalah yang diukur dalam tes ini ditunjukkan pada TABEL 3.

TABEL 3. Indikator kemampuan pemecahan masalah

\begin{tabular}{cl}
\hline No & \multicolumn{1}{c}{ Indikator Kemampuan Pemecahan Masalah } \\
\hline 1. & Mendeskripsikan variabel yang diketahui pada masalah. \\
2. & Menuliskan konsep yang digunakan untuk menyelesaikan \\
& masalah. \\
3. & Menggunakan variabel dalam menerapkan konsep. \\
4. & Mengecek dan mengevaluasi solusi. \\
\hline
\end{tabular}

Untuk mengetahui kemampuan seluruh siswa dalam memecahkan masalah di setiap aspeknya maka perlu dihitung persentase tiap aspek. Penghitungan persentase aspek pemecahan masalah dengan menggunakan persamaan 1 .

$$
P_{x}=\frac{R_{x}}{n s_{x}} \times 100 \%
$$

Keterangan :

$$
\begin{aligned}
& \mathrm{x}=\text { Aspek A, B, C, dan D } \\
& \mathrm{Px}=\text { Persentase Aspek } \mathrm{x} \\
& \mathrm{Rx}=\text { Perolehan Skor Aspek } \mathrm{x} \\
& \mathrm{Sx}=\text { Skor Maksimal Aspek } \mathrm{x} \\
& \mathrm{n} \quad=\text { Jumlah Siswa yang Ikut Tes }
\end{aligned}
$$

Kemudian persentase tersebut diberikan kriteria seperti ditunjukkan pada TABEL 4.

TABEL 4. Kriteria persentase aspek pemecahan masalah

\begin{tabular}{rc}
\hline Persentase Aspek & Kriteria \\
\hline $\mathbf{8 0}<\mathbf{P x} \leq \mathbf{1 0 0}$ & Sangat Tinggi (ST) \\
$\mathbf{6 0}<\mathbf{P x} \leq \mathbf{8 0}$ & Tinggi (T) \\
$\mathbf{4 0}<\mathbf{P x} \leq \mathbf{6 0}$ & Cukup (C) \\
$\mathbf{2 0}<\mathbf{P x} \leq \mathbf{4 0}$ & Rendah (R) \\
$\mathbf{P x} \leq \mathbf{2 0}$ & Sangat Rendah (SR)
\end{tabular}

Angket tanggapan siswa bertujuan untuk memperoleh informasi tentang tanggapan siswa terhadap proses pembelajaran fisika yang diterapkan guru selama ini. Angket yang dikembangkan dalam penelitian ini berbentuk skala Likert, dengan menggunakan empat kategori tanggapan yaitu; sangat setuju (SS), setuju (S), tidak setuju (TS),dan sangat tidak setuju (STS). Angket terdiri dari dari pernyataan positif dan pernyataan negatif agar data yang diperoleh menjadi lebih baik. Indikator tanggapan siswa disajikan pada Tabel 5. Data yang diperoleh melalui angket dianalisis secara deskriptif untuk menemukan kecenderungan saat penelitian. Teknik wawancara yang digunakan dalam penelitian ini adalah wawancara semi terstruktur (semi-structure interview). 
TABEL 5. Indikator angket tanggapan siswa

\begin{tabular}{cl}
\hline No & \multicolumn{1}{c}{ Indikator Tanggapan Siswa } \\
\hline 1. & $\begin{array}{l}\text { Model pembelajaran yang digunakan guru pada konsep gerak lurus sangat } \\
\text { menyenangkan }\end{array}$ \\
\hline 2. & $\begin{array}{l}\text { Model pembelajaran yang digunakan guru pada konsep gerak lurus memotivasi } \\
\text { siswa untuk menyelesaikan masalah }\end{array}$ \\
\hline 3. & $\begin{array}{l}\text { Guru tidak membimbing siswa dalam menyelesaikan masalah fisika terkait gerak } \\
\text { lurus }\end{array}$ \\
\hline 4. & $\begin{array}{l}\text { Model pembelajaran yang digunakan guru pada konsep gerak lurus dapat } \\
\text { memudahkan siswa dalam menyelesaikan masalah fisika }\end{array}$ \\
\hline 5. & $\begin{array}{l}\text { Model pembelajaran yang digunakan guru pada konsep gerak lurus dapat melatih } \\
\text { siswa dalam mengidentifikasi masalah }\end{array}$ \\
\hline 6. & $\begin{array}{l}\text { Model pembelajaran yang digunakan guru pada konsep gerak lurus menyebabkan } \\
\text { siswa merasa kesulitan menggunakan konsep fisika dalam menyelesaikan masalah }\end{array}$ \\
\hline 7. & $\begin{array}{l}\text { Keinginan untuk menggunakan lagi model pembelajaran yang digunakan guru } \\
\text { pada konsep gerak lurus pada materi yang lain }\end{array}$ \\
\hline
\end{tabular}

\section{HASIL DAN PEMBAHASAN}

\section{Kemampuan Pemecahan Masalah Siswa}

Hasil analisis data kemampuan pemecahan masalah ditunjukkan pada GAMBAR 1.

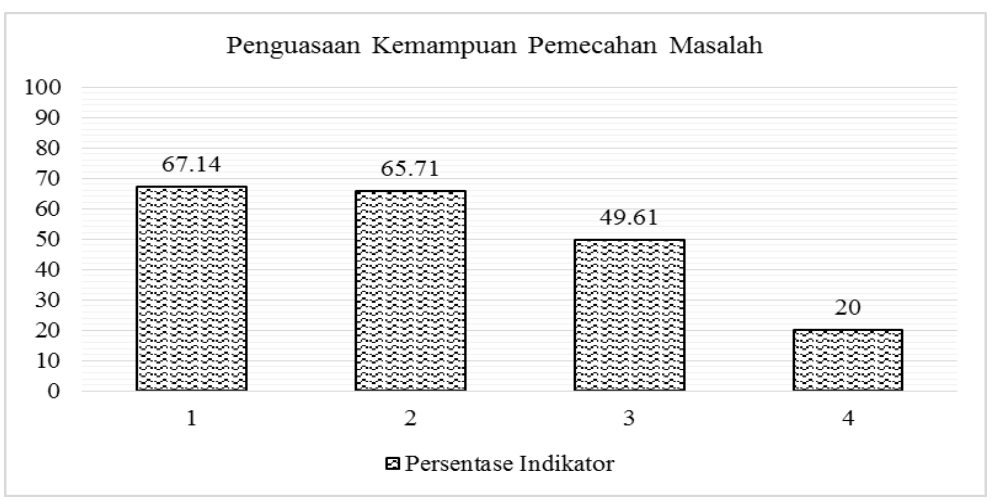

GAMBAR 1. Penguasaan kemampuan pemecahan masalah Fisika

Berdasarkan GAMBAR 1 dapat dilihat bahwa kemampuan siswa dalam mendeskripsikan masalah memperoleh skor $67,14 \%$ dengan kriteria tinggi. Perolehan skor untuk kemampuan siswa dalam merencanakan masalah yakni $65,71 \%$ yang termasuk dalam kriteria tinggi juga. Untuk kemampuan siswa dalam melaksanakan/ketepatan solusi memperoleh skor $49,61 \%$ dengan kriteria cukup, sedangkan kemampuan siswa dalam mengevaluasi solusi memperoleh skor terendah yakni 20,00\% yang termasuk dalam kriteria sangat rendah. Jika dikalkulasikan secara umum, maka perolehan ratarata skor kemampuan pemecahan masalah siswa yaitu sebesar 52,57\% dengan kategori cukup.

Hasil penelitian yang diperoleh tersebut menunjukkan bahwa kemampuan pemecahan masalah Fisika masih berada dalam kategori yang cukup. Hal ini terjadi salah satu kemungkinan karena banyak siswa yang belum memahami konsep Fisika yang telah diajarkan, sebagaimana hasil wawancara yang dilakukan terhadap siswa. Hal ini diperkuat juga oleh Fajarudin (2012) bahwa kemampuan pemecahan masalah mempersyaratkan penguasaan konsep sebagai dasarnya. Penguasaan konsep dapat diabstraksikan sebagai landasan untuk memperoleh kemampuan pemecahan masalah, berpikir kreatif dan kritis, dan pengambilan keputusan. 
Sebagaimana Marzano dalam Anita (2007) yang menyatakan bahwa pemecahan masalah merupakan suatu proses yaitu proses berpikir atau proses mental dan aplikasi pengetahuan yang telah diperoleh, hendaknya kemampuan pemecahan masalah ini jadi perhatian oleh guru agar selalu dilatihkan dalam proses pembelajaran. Dengan seringnya melakukan latihan memecahkan masalah fisika ini diharapkan kemampuan pemecahan masalah siswa mengalami peningkatan. Hal tersebut diperkuat dengan hasil riset yang telah membuktikan mengenai proses pemecahan masalah. Gerace, J. W. et al (2005) menyatakan bahwa kemampuan pemecahan masalah seorang siswa tidak hanya tergantung pada tingkat kematangannya tetapi juga ditentukan dari permasalahan yang mereka sendiri mengalaminya. Ia menyimpulkann bahwa kemampuan untuk memecahkan suatu masalah, tidak hanya ditentukan oleh pola pikir melainkan dipengaruhi oleh kerja atau pelatihan.

Proses berpikir atau proses mental sebagaimana yang diharapkan memang tidak dijumpai dalam proses pembelajaran yang dilakukan oleh guru. Dalam kegiatan observasi yang peneliti lakukan, proses pembelajaran yang diterapkan tidak sesuai dengan dokumen rencana pembelajaran (Silabus, RPP). Jika dalam RPP disebutkan bahwa model pembelajaran yang akan diterapkan yakni pembelajaran saintifik, namun proses pembelajaran yang diterapkan masih bersifat konvensional yakni berupa ceramah dan proses pembelajaran masih beroriantasi pada guru.

Kondisi tersebut sebetulnya sangat disayangkan sehingga berdampak terhadap minat belajar siswa dan kemampuan siswa dalam memecahkan masalah. Hal tersebut disampaikan siswa saat peneliti melakukan wawancara. Siswa merasakan pembelajaran yang diterapkan guru dirasakan sangat monoton. Para siswa juga menyatakan bahwa guru kurang maksimal dalam memberikan bimbingan terhadap siswa karena guru sering memberikan bimbingan terhadap siswa yang duduk di depan. Sehingga siswa yang duduk di belakang merasa kurang diperhatikan.

Proses pembelajaran yang dilakukan berdampak terhadap hasil belajar siswa dalam kemampuan pemecahan masalah fisika. Sebagaimana hasil penelitian pada GAMBAR 1, kategori kemampuan siswa dalam mendeskripsikan masalah masih memperoleh skor 67,14\%. Meskipun sudah berkategori tinggi namun skor tersebut tidak terpaut jauh dengan kategori cukup. Hal tersebut menunjukkan masih banyak siswa yang belum mampu memahami masalah yang diberikan oleh guru. Jika siswa sudah kesulitan dalam memahami masalah, sudah tentu siswa juga akan kesulitan dalam membuat rencana solusi untuk menyelesaikannya. Dapat dilihat juga dalam GAMBAR 1, kemampuan merencanakan solusi memperoleh skor lebih rendah yakni 65,71\%. Data tersebut menunjukkan semakin banyak siswa yang kesulitan dalam membuat rencana untuk menyelesaikan masalah. Skor yang lebih rendah ini disebabkan karena banyak siswa yang tidak mengerti dengan masalah yang diberikan.

Ketika siswa sudah kesulitan dalam merencanakan solusi, tentu akan berdampak terhadap ketepatan solusi yang diberikan. Sebagaimana data pada GAMBAR 1 menunjukkan kategori ketepatan solusi hanya memperoleh skor $49,61 \%$. Hal ini menunjukkan masih banyak siswa yang tidak tepat dalam memberikan solusi sehingga masalah yang diberikan tidak terselesaikan dengan baik dan tepat. Sedangkan untuk kategori evaluasi solusi memperoleh skor yang paling rendah yakni $20,00 \%$.

Dari data hasil penelitian secara keseluruhan menunjukkan bahwa adanya penurunan skor yang diperoleh dari tiap kategori. Jika siswa sudah bermasalah pada kategori pertama, maka akan bermasalah juga pada kategori berikutnya. Hal ini disebabkan karena pemecahan masalah merupakan suatu proses berfikir (learning to think) atau belajar bernalar (learning to reason), yaitu berfikir atau bernalar mengaplikasikan pengetahuan-pengetahuan yang telah diperoleh sebelumnya untuk memecahkan masalah-masalah baru yang belum pernah dijumpai (Leeuw dalam Osarizalsyam, 2006).

Hasil ini bisa dijadikan bahan evaluasi untuk memberikan proses pembelajaran yang lebih berkualitas dan bisa mengembangkan model pembelajaran, yakni model pembelajaran yang menekankan pemecahan masalah yang melibatkan pola-pola berfikir tingkat tinggi dengan memberi peluang kepada siswa untuk mengembangkan pengetahuan dan pemahaman konseptual secara lebih bermakna, keterampilan-keterampilan kognitif secara bebas, pemikiran kreatif dan kritis, rasa percaya diri dalam menerapkan pengetahuan untuk memecahkan masalah dan pengambilan keputusan dalam lingkungan yang senantiasa berubah. Kemampuan-kemampuan tersebut dibangun oleh siswa ketika dia dihadapkan pada persoalan-persoalan yang bervariasi (Santyasa, 2007). 


\section{Tanggapan Siswa}

Hasil analisis data angket tanggapan siswa terhadap proses pembelajaran yang dilakukan guru ditunjukkan pada GAMBAR 2.

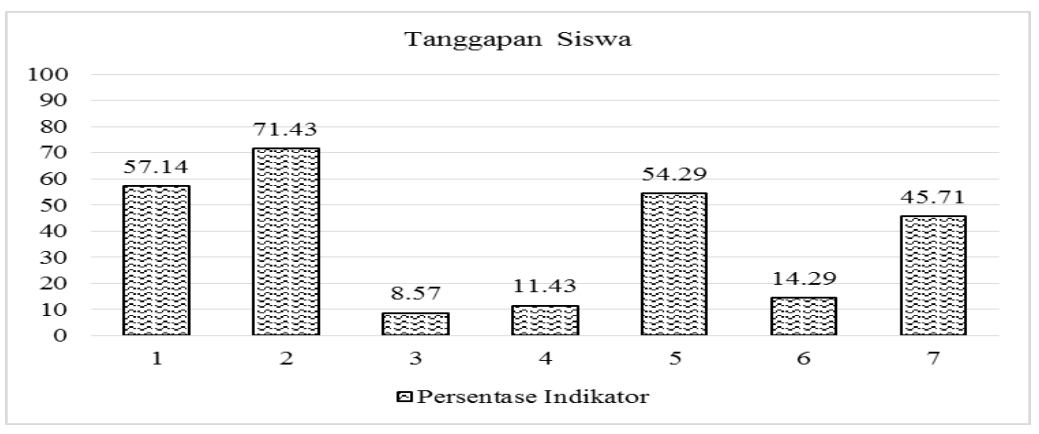

GAMBAR 2. Hasil tanggapan siswa

Berdasarkah hasil analisis data pada GAMBAR 2 dapat disimpulkan bahwa guru cenderung menggunakan model pembelajaran yang sama ketika mengajarkan materi-materi Fisika yang lain. Pernyataan ini juga muncul ketika dilakukan wawancara kepada guru dan siswa. Ketika di wawancara, guru memang menyatakan bahwa pembelajaran yang biasa dilakukan adalah guru menjelaskan materi kemudian memberikan contoh soal dan siswa diberikan soal-soal latihan untuk dikerjakan. Hal ini dilakukan karena pengaruh karakter soal saat ujian nasional sehingga guru berorientasi kepada bagaimana siswa bisa mengerjakan soal-soal dengan baik. Begitu juga dengan siswa, ketika dilakukan wawancara hampir semua siswa menyatakan bahwa model pembelajaran guru cenderung sama dengan ketika mengajarkan materi Fisika lainya.

Selain itu dapat juga disimpulkan bahwa siswa menginginkan perubahan proses pembelajaran yang dilakukan guru untuk materi yang lain karena hanya $45.71 \%$ siswa yang menginginkan model pembelajaran ini digunakan lagi. Hal yang menarik dari analisis data adalah diperoleh data bahwa 71.43\% siswa termotivasi untuk menyelesaikan masalah Fisika dan ini merupakan skor tertinggi. Setelah ditelusuri melalui wawancara hal ini dikarenakan siswa sangat menyenangi pembawaan guru Fisikanya karena gurunya masih muda sehingga bisa lebih memahami dan menyelami kehidupan siswa. Selain itu guru Fisika sangat mudah bergaul dan dekat dengan siswa sehingga siswa merasa termotivasi untuk menyelesaikan masalah yang diberikan.

\section{PENUTUP}

Kesimpulan yang diperoleh berdasarkan hasil penelitian yang telah dilakukan dapat dijelaskan sebagai berikut:

1) Kegiatan pembelajaran Fisika yang dilakukan guru di sekolah selama ini cenderung sama dengan materi pada bab sebelumnya yaitu berupa penjelasan materi kemudian dilanjutkan dengan pemberian contoh soal dan kemudian menjelang akhir pembelajaran siswa diberikan latihanlatihan soal sehingga pembelajaran cenderung berpusat pada guru.

2) Kegiatan pembelajaran Fisika yang dilakukan guru selama ini kurang melatihkan keterampilan berpikir tingkat tinggi terutama kemampuan pemecahan masalah siswa. Terbukti dengan skor rata-rata persentase kemampuan pemecahan masalah siswa kurang memuaskan. Hal ini menyebabkan hasil belajar kognitif fisika siswa juga belum memuaskan karena masih di bawah kriteria ketuntasan minimal.

3) Siswa cenderung tidak menginginkan proses pembelajaran Fisika yang dilakukan selama ini digunakan lagi pada proses pembelajaran berikutnya. 


\section{UCAPAN TERIMA KASIH}

Peneliti mengucapkan banyak terima kasih kepada kepala sekolah, guru, dan siswa kelas X di salah satu SMA Negeri Kabupaten Sukabumi yang telah berkontribusi dalam kegiatan penelitian ini.

\section{REFERENSI}

Anita, 2007, 'Model Pembelajaran Thinking Aloud Pair Problem Solving (TAPPS) pada Topik Larutan Penyangga Untuk Meningkatkan Pemahaman Konsep dan Kemampuan Pemecahan Masalah Siswa', (Unpublished Magister Thesis), Program Pasca Sarjana UPI, Bandung.

Depdiknas, 2008, 'Strategi Pembelajaran MIPA', Dikti Ditjen PMPTK Jakarta.

Fajarudin, M. F., 2012, 'Pengaruh Model Pembelajaran Inkuiri Terbimbing Berbantuan Website Terhadap Penguasaan Konsep dan Kemampuan Pemecahan Masalah Siswa Kelas X pada Topik Listrik Arus Searah', (Unpublished Magister Thesis), Program Pasca Sarjana UPI, Bandung.

Gerace, W.J, et al., 2005, 'Teaching vs. Learning: Changing Perspectives on Problem Solving in Physics Instruction', 9th Common Conference of the Cyprus Physics Association and Greek Physics Association.

Gok, T. \& Silay, I.,2010, 'The Effects of Problem Solving Strategies on Students' Achievement, Attitude and Motivation', Lat. Am. J. Phys. Educ, Vol. 4, No. 1.

Heller, P. \& Keneth, 1999, 'Cooperative Group Problem Solving in Physics', Kansas, University of Minnesota.

National Science Teachers Association in Collaboration with the Association for the Education of Teachers in Science (NSTA), 2003, 'Standards for ScienceTeacher Preparation'.

Osarizalsyam, 2006, 'Penerapan Model Pembelajaran Kooperatif tipe Dua Tinggal Dua Tamu (Two Stay Two Stray) Pada Konsep Ekosistem untuk Kemampuan Pemecahan Masalah dan Hasil Belajar siswa' (Unpublished Magister Thesis), Program Pasca Sarjana UPI, Bandung.

Purba, J. P. 2003, 'Pengembangan Dan Implementasi Model Pembelajaran Fisika Menggunakan Pendekatan Pemecahan Masalah', (Unpublished Doctoral Dissertation), Program Pasca Sarjana UPI, Bandung.

Santyasa, I. W. 2007, 'Pengembangan Pemahaman Konsep Dan Kemampuan Pemecahan Masalah Fisika Bagi Siswa SMA Dengan Pemberdayaan Model Perubahan Konseptual Berseting Investigasi Kelompok', Jurnal Pendidikan Fisika Universitas Pendidikan Ganesha.

Sugiyono, 2013, 'Metode Penelitian Pendidikan; Pendekatan Kuantitatif, Kualitatif, dan R\&D' Bandung, Alfabeta.

Trianto, 2013, 'Mendesain Model Pembelajaran Inovatif - Progresif : Konsep, Landasan, dan Implementasinya Pada Kurikulum Tingkat Satuan Pendidikan (KTSP)', Jakarta, Kencana Prenada Media Group.

Trilling, B. \& Fadel, C., 2009, '21st Century Skills: Learning for Life in Our Times', San Francisco, John Wiley \& Sons, Inc. 